\title{
ONLINE CLASSES' EFFECTS DURING COVID 19 LOCKDOWN - TEACHERS' VS. STUDENTS' PERSPECTIVE, CASE OF THE SCHOOL OF ENGINEERING MANAGEMENT
}

\author{
Tatjana Ilić-Kosanović ${ }^{1}$ \\ Damir Ilić ${ }^{2}$
}

DOI: https://doi.org/10.31410/LIMEN.S.P.2020.101

\begin{abstract}
In the second decade of the $21^{\text {st }}$ century, there is an ongoing discussion on the value of online classes in higher education as the implementation of new technologies in the higher education processes is on the rise. The main questions that are emerging are the level of interactions, quality of knowledge transfer, and development of critical thinking. Several previously conducted research concluded that online models of higher education teaching add more value than traditional methods, and some of the research has shown the shortcomings of online higher education programs. The pandemic of Covid-19 disease caused by a Corona Virus (SARS-CoV-2) has forced most of the higher education institutions in Europe to transfer almost the entire educational process to online platforms.

In this paper, the satisfaction of the teachers and the students with the online classes' effectiveness regarding the teacher-student communication, knowledge transfer, and development of critical thinking in the case of the School of Engineering Management in Belgrade, Serbia, is researched through a short survey and interviews. Statistical analysis has shown that there is a statistically significant difference between students' and teachers' satisfaction. Furthermore, in short interviews, it is shown that the students are more receptive to knowledge transfer, teacher-student communication, and the development of critical thinking through online classes than the professors. As the sample is small, further empirical research on the wider sample is needed in order to get more compelling conclusions.
\end{abstract}

Keywords: Online classes, Covid-19 pandemic, Teachers, Students, Knowledge transfer, Higher education.

\section{INTRODUCTION}

I n the second decade of the $21^{\text {st }}$ century, as the number of online courses is constantly growing, there are ongoing discussions on the value of online classes in all levels of formal and informal education (Hollis, 2018; Baker, et al., 2019; Hermond \& Tanner, 2020). It is particularly noticeable in higher education as the implementation of new technologies in higher education teaching processes is on the rise. Among other relevant questions, the main issues that are emerging are the levels of teacher-student interactions, the quality of knowledge transfer, and the development of students' critical thinking. A variety of research brings different conclusions. Several of the previously conducted research have concluded that online models of higher education teaching add value more than traditional methods, and some of the research has shown the shortcomings of online higher education programs.

\footnotetext{
1 University „Union - Nikola Tesla“, School of Engineering Management, Bulevar vojvode Misica 43, 11000 Belgrade, Serbia

2 University „Union - Nikola Tesla“, School of Engineering Management, Bulevar vojvode Misica 43, 11000 Belgrade, Serbia
} 
Many of the higher education institutions have searched during the last decade for suitable solutions for online learning to be included in their programs, with mixed success and satisfaction with the outcome. However, the incidence of the pandemic of Covid-19 disease caused by a Corona Virus (Severe Acute Respiratory Syndrome Coronavirus 2 - SARS-CoV2) in 2020 suddenly forced most of the higher education institutions in Europe to transfer, at least for a [so far] short period (currently less than a year), their almost entire educational process to online forms. Higher education institutions in the Republic of Serbia have also started to transfer almost all of their teaching process to online forms (whether they are accredited for that or not) after the announcement of the State of emergency on March 15, 2020 (Službeni glasnik, 2020). It has been the main form of teaching until the end of May after the abolishment of the State of emergency. Most of the institutions have continued with the hybrid model in the Fall semester, although the teaching process during the state of emergency circumstances (most of the Summer semester) is the main focus of this research. Actually, in the Republic of Serbia, this has been a hybrid model that has included online lectures and exercises, but not the exams and the tests which by Serbian Law on Higher Education can be conducted solely at a higher education institution premises (Republika Srbija, 2017).

In this paper satisfaction of the teachers and the students with the online classes' effectiveness regarding the teacher-student communication, knowledge transfer, and development of students' critical thinking in the case of the School of Engineering Management in Belgrade, Serbia, is researched through a short survey and interviews.

\section{ONLINE CLASSES’ EFFECTS - LITERATURE REVIEW}

From the beginning of the $21^{\text {st }}$ century, the number of higher education institutions including either online programs or some online classes is growing and the implementation of new technologies in higher education teaching processes is rapidly increasing (Hollis, 2018; Baker, et al., 2019; Hermond \& Tanner, 2020). The number of students who take at least one online course is on the constant rise since the early 2000s (Yang \& Cornelius, 2004). At the same time, hybrid models of teaching are also emerging, joining web-based teaching with the traditional, campus, teaching (Alexander, et al., 2014; Estacio \& Raga, 2017; Bettinger, Fox, Loeb \& Taylor, 2017).

The main issues that are emerging are the levels of interaction between the students and their teachers (Chen \& Chen, 2007; Parks-Stamm, Zafonte and Palenque, 2017) and the ability to communicate in new ways (more discussion groups, etc.); the knowledge transfer (Chen \& Chen, 2007); and the quality of knowledge transferred from the teachers to the students. Students' development of critical thinking skills is also one of the crucial focal points of researching the online classes' effects (Parks-Stamm, Zafonte, and Palenque, 2017), as it is one of the key activities of higher education teaching processes. Critical thinking has many definitions, one of the most appropriate is the one by Heard, Scoular, Duckworth, Ramalingam and Teo (2020):

'To think critically is to analyse and evaluate information, reasoning and situations, according to appropriate standards, to construct sound and insightful new knowledge, understandings, hypotheses and beliefs. Critical thinking encompasses the subject's ability to process and synthesise information in such a way that it enables them to apply it judiciously to tasks for informed decision-making and effective problem-solving'.

Other issues are gaining importance. One of the issues arising is cheating during the online courses (Hollis, 2018), especially during the tests, quizzes, etc., especially in the cases when 
cheating is going to the extent of hiring so-called ghost student who takes exams or writes papers instead of a student, as they are not visible while taking an online test or writing a paper, which is the costly but very easy solution for the students who do not or cannot commit to their obligations. It also raises another issue for other research, it is noted that part-time teaching staff overburdened with obligations in various institutions are less likely to focus on this issue than the ones employed full time, which opens a completely new topic for the research (Hollis, 2018). Some of the research is focused on time management issues for the students who take online classes that can cause problems in achieving academic success because a more relaxing schedule often brings more delaying in completing the tasks (Baker, et al., 2019), especially for the students who require more supervising, guidance, and mentoring.

The incidence of the pandemic of Covid-19 disease caused by a Corona Virus (SARS-CoV-2) last spring forced most of the higher education institutions in Europe and all over the world (Aristovnik, Keržič, Ravšelj, Tomaževič, Umek, 2020; Desai, et al., 2020; Engle, 2020; Pažun \& Langović 2020; Trout, 2020) to transfer completely to the online forms of teaching, using platforms that include Zoom, Microsoft Teams and other platforms (Roy, et al., 2020). Zhu and Liu (2020) have stated that one of the major advantages of this mode of classes are the possibility to access the class from anywhere, and a capacity for new modes of teaching that include extra students' involvement and additional interaction between the students and teachers (discussions, etc.). The teaching process is changing from teacher-oriented to students oriented process (Alawamleh, Al-Twait, Al-Saht, 2020; Zhu \& Liu, 2020). There is also one of the technical problems arising, namely poor Internet quality in some areas, which opens up more substantial, the topic of accessibility of knowledge for the students that live in underdeveloped areas with a poor internet connection (Aristovnik, Keržič, Ravšelj, Tomaževič, Umek, 2020).

Also, there is an important problem emerging for other research, namely the classes that cannot be organized in the online form, such is the practical courses in medicine (Engle, 2020), and other courses that require lab work.

\section{MATERIALS AND METHODS}

\section{Objectives and survey design}

School of Engineering Management is a private higher education institution in Belgrade, Republic of Serbia, a part of the "University Union - Nikola Tesla", with accredited undergraduate programs Engineering Management and Management; master programs Project Management and Industry 4.0, Engineering and Management of Security Information Systems, Economics and Management of Energy, and newly accredited Ph.D. program Waste Management. The School of Engineering Management has been forced to transfer completely to online forms of teaching due to the pandemic of Covid-19 disease. Online classes at the School began on March 23, a week after the state of emergency has been announced and the teaching has been organized through Zoom platform with the Google classroom used for disseminating teaching materials and announcements.

The satisfaction of the teachers and the students with the online classes' effectiveness regarding the teacher-student communication, knowledge transfer and development of critical thinking in the case of the School of Engineering Management in Belgrade, Serbia, is researched through short surveys and interviews. The survey has been organized from June $8^{\text {th }}$ to $12^{\text {th }}$, and the series of short interviews have been organized from June $22^{\text {nd }}$ to $26^{\text {th }}$ through short, in- 
person, semi-structured interviews. They have been asked to identify the main advantages and disadvantages of online classes regarding teacher-student communication, knowledge transfer, and development of critical thinking at the Institution during the pandemic online classes.

For the main research questions, a five-point Likert scale has been used to measure the statements (coded as follows: 1 - I disagree completely; 2 - I disagree; 3 - I am neutral; 4 - I agree; 5 - I agree completely). The constructed scale has been subjected to the test of reliability and it have had good (0.979) Cronbach's Alpha value, which indicates an acceptable level of internal consistency for the scale with the specific sample used for the study.

Table 1. Reliability Statistics

\begin{tabular}{|r|r|r|}
\hline Cronbach's Alpha & $\begin{array}{c}\text { Cronbach's Alpha Based on } \\
\text { Standardized Items }\end{array}$ & N of Items \\
\hline .721 & .723 & 3 \\
\hline
\end{tabular}

Source: authors

It is assumed $\left(\mathrm{H}_{1}\right)$ that there is a statistically significant difference in the satisfaction of students and teachers with online classes' effectiveness in the teacher-student interaction, knowledge transfer, and development of critical thinking. Several sub hypotheses have been developed further, stating that there is a statistically significant difference in the opinion of the students and teachers on the online classes' effectiveness in:

- $\mathrm{H}_{1 \mathrm{a}}$ : Teacher-student interaction;

- $\mathrm{H}_{1 \mathrm{~b}}$ : Knowledge transfer;

- $\mathrm{H}_{1 \mathrm{c}}$ : Development of critical thinking;

$\mathrm{H}_{0}$ states that there is no statistically significant difference in the satisfaction of students and teachers regarding online classes' effectiveness in the teacher-student communication, knowledge transfer, and development of critical thinking.

Collected data have been tabularized and subjected to statistical analyses by using statistical package SPSS v. 18.

\section{Description of the sample}

For the purpose of this research, the students of undergraduate and master programs have been targeted, same with the teaching staff in various ranks. The total sample size has been 81 $(\mathrm{N}=81)$, among them $43(53.1 \%)$ have been the students and 38 (46.9\%) professors (Table 2). Participants have been randomly chosen to represent each year of undergraduate studies and master studies among the students, and to represent each teaching rank among teaching staff: teaching associates, teaching assistants, languages professors, assistant professors, associate professors, and full professors.

Table 2. Survey Demographics

\begin{tabular}{|l|l|r|r|r|r|}
\hline \multicolumn{2}{|c|}{} & Frequency & Percent & Valid Percent & $\begin{array}{c}\text { Cumulative } \\
\text { Percent }\end{array}$ \\
\hline \multirow{5}{*}{ Students } & I year & 11 & 13.6 & 13.6 & 13.6 \\
\cline { 2 - 6 } & II year & 10 & 12.3 & 12.3 & 25.9 \\
\cline { 2 - 6 } & III year & 6 & 7.4 & 7.4 & 33.3 \\
\cline { 2 - 6 } & IV year & 7 & 8.6 & 8.6 & 42.0 \\
\cline { 2 - 6 } & Master & 9 & 11.1 & 11.1 & 53.1 \\
\hline
\end{tabular}




\begin{tabular}{|l|l|r|r|r|r|}
\hline \multirow{5}{*}{ Teachers } & Teaching associate & 7 & 8.6 & 8.6 & 61.7 \\
\cline { 2 - 6 } & Teaching assistant & 6 & 7.4 & 7.4 & 69.1 \\
\cline { 2 - 6 } & Languages professor & 5 & 6.2 & 6.2 & 75.3 \\
\cline { 2 - 6 } & Assistant professor & 6 & 7.4 & 7.4 & 82.7 \\
\cline { 2 - 6 } & Associate professor & 6 & 7.4 & 7.4 & 90.1 \\
\cline { 2 - 6 } & Full professor & 8 & 9.9 & 9.9 & 100.0 \\
\cline { 2 - 6 } & Total & 81 & 100.0 & 100.0 & \\
\hline
\end{tabular}

Source: authors

After the survey, one participant for each group has been randomly chosen for the interviewing. Demographical profile of the participants is given in Table 3.

Table 3. Demographic of interviewees

\begin{tabular}{|c|l|c|}
\hline Code Name & \multicolumn{1}{|c|}{ Profile } & $\begin{array}{c}\text { Gender } \\
\text { (F/M) }\end{array}$ \\
\hline P1 & Student, I year, undergraduate studies & $\mathrm{F}$ \\
\hline P2 & Student, II year, undergraduate studies & $\mathrm{M}$ \\
\hline P3 & Student, III year, undergraduate studies & $\mathrm{F}$ \\
\hline P4 & Student, IV year, undergraduate studies & $\mathrm{M}$ \\
\hline P5 & Master student & $\mathrm{F}$ \\
\hline P6 & Teaching associate & $\mathrm{f}$ \\
\hline P7 & Teaching assistant & $\mathrm{M}$ \\
\hline P8 & Languages teacher & $\mathrm{F}$ \\
\hline P9 & Assistant professor & $\mathrm{F}$ \\
\hline P10 & Associate professor & $\mathrm{M}$ \\
\hline P11 & Full professor & $\mathrm{M}$ \\
\hline
\end{tabular}

Source: authors

\section{RESULTS AND DISCUSSION}

One-way ANOVA has been applied to formally test the hypotheses. The significance level $(\alpha)$ has been set as .05. Descriptive statistical results are shown in Table 4.

Table 4. Descriptive statistics

\begin{tabular}{|c|c|c|c|c|c|}
\hline & & $\mathrm{N}$ & Mean & Std. Deviation & Std. Error \\
\hline \multirow{3}{*}{ Teacher-student interaction } & Students & 43 & 3.63 & .536 & .082 \\
\hline & Professors & 38 & 2.39 & .755 & .122 \\
\hline & Total & 81 & 3.05 & .893 & .099 \\
\hline \multirow{3}{*}{ Knowledge transfer } & Students & 43 & 3.58 & .663 & .101 \\
\hline & Professors & 38 & 2.47 & .647 & .105 \\
\hline & Total & 81 & 3.06 & .857 & .095 \\
\hline \multirow{3}{*}{$\begin{array}{l}\text { Development of critical } \\
\text { thinking }\end{array}$} & Student & 43 & 3.60 & .495 & .075 \\
\hline & Professors & 38 & 2.71 & .768 & .125 \\
\hline & Total & 81 & 3.19 & .776 & .086 \\
\hline
\end{tabular}

Source: authors

Before beginning with One way ANOVA analysis, several assumptions have to be met, and one of the main assumptions for One way ANOVA is that there has to be the equality of variance 
among the various categories under consideration. Levene's test for Equality of Variances has been carried out as a measure for the homogeneity of variance among the various categories.

Table 5. Test of Homogeneity of Variances

\begin{tabular}{|l|r|r|r|r|}
\hline & Levene Statistic & df1 & df2 & \multicolumn{1}{c|}{ Sig. } \\
\hline Teacher-student interaction & 5.434 & 1 & 79 & .022 \\
\hline Knowledge transfer & .008 & 1 & 79 & .929 \\
\hline $\begin{array}{l}\text { Development of critical } \\
\text { thinking }\end{array}$ & 7.728 & 1 & 79 & .007 \\
\hline
\end{tabular}

Source: authors

As Sig $(p)$ values less than 0.05 indicate that the variance among the various categories is not the same for the first and the third research question, Welch's ANOVA has been used instead. In this analysis Welch's Sig values have been considered.

Table 6. Robust Tests of Equality of Means

\begin{tabular}{|l|l|r|r|r|r|}
\hline \multicolumn{2}{|l|}{} & Statistic $^{\mathrm{a}}$ & \multicolumn{1}{|c|}{ df1 } & \multicolumn{1}{c|}{ df2 } & \multicolumn{1}{c|}{ Sig. } \\
\hline Teacher-student interaction & Welch & 70.200 & 1 & 65.777 & .000 \\
\hline Knowledge transfer & Welch & 57.797 & 1 & 78.213 & .000 \\
\hline $\begin{array}{l}\text { Development of critical } \\
\text { thinking }\end{array}$ & Welch & 37.696 & 1 & 61.798 & .000 \\
\hline
\end{tabular}

a. Asymptotically F distributed.

Source: authors

As the $\operatorname{Sig}(\mathrm{p})$ values are in this case less than 0.05 , the main research hypothesis $\left(\mathrm{H}_{1}\right)$ that there is a statistically significant difference in the satisfaction of students and teachers with online classes' effectiveness in the teacher-student interaction, knowledge transfer, and development of critical thinking is accepted. Each sub hypotheses are accepted.

In further interviews with the students and teaching staff, the students expressed their satisfaction with the online teaching process (P1, P3, P4, P5), namely, P4 expressed satisfaction with the ability to participate in online discussions, to ask questions and to get answers in realtime, P2 and P5 have expressed satisfaction with the ability to follow up recorded classes, with the opportunity of additional effort in searching online databases of academic articles to further develop the knowledge. Overall, none of them felt that communication with the professors has been damaged by transferring from "real" to "virtual" world. Also, the students have seemed more at ease in using mobile phones, tablets, lap tops, net books and PC's as learning tools.

On the other side, the professors felt (P7, P10, P11) that the process of teaching itself has been much better than anticipated, and that the lectures have been delivered in a proper way. Nevertheless, they have expressed frustration with the efforts to include all students in the discussions and concern that the students have been lacking "live" interaction, stating that they believe that the students acquire knowledge better in traditional forms of classes and discussions.

Some of the concerns that have been voiced by the students and teachers are presented at Table 7 , which can be further analysed in developing online learning processes. 
Table 7. Major online classes concerns

\begin{tabular}{|l|l|}
\hline Students' perspective & Teachers' perspective \\
\hline $\begin{array}{l}\text { Inability to interact in real-time (not ready } \\
\text { to answer questions) }\end{array}$ & $\begin{array}{l}\text { Difficulties to include all participants in } \\
\text { discussions in groups larger than ten students. }\end{array}$ \\
\hline $\begin{array}{l}\text { Inability to see the teacher if the } \\
\text { presentation open. }\end{array}$ & $\begin{array}{l}\text { Students are not asking for clarification until } \\
\text { after the lecture. }\end{array}$ \\
\hline $\begin{array}{l}\text { Difficulties to participate in online } \\
\text { discussions }\end{array}$ & Concern of the value of knowledge transfer. \\
\hline
\end{tabular}

Source: Authors based on interviews

Based on the results of the interviews, the authors propose a model for the development of new curricula that will include online models of teaching not only for the possibility of other extraordinary circumstances incidence but in order to blend traditional and online teaching that can be further improved and developed for future generations.

The basic activity would consist of developing programs that would include elements of facilitating real-time teacher - students' interaction, means of establishing knowledge transfer and modes of discussions that would improve the critical thinking of the students. The second step would be the implementation of the programs which would include discussion groups, group and individual presentations. This would lead to the third step, specifically, the students' assessment through tests and quizzes that would provide an objective assessment of the students' knowledge through grading. After completion of a program and grading, the students and the teachers would be surveyed and interviewed regarding their experiences and attitudes, which would complete the evaluation of the programs. Final evaluation would help to revise and improve the programs.

Figure 1. Proposed model of online classes development and assessment

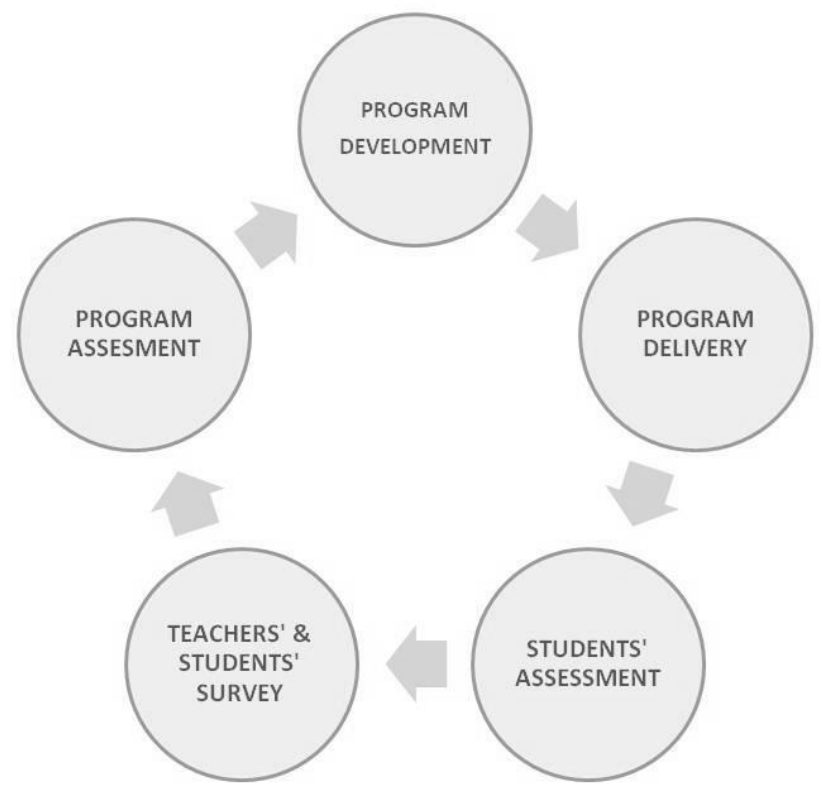

Source: Authors 


\section{FUTURE RESEARCH DIRECTIONS}

As a study of one higher education institution, this research has major limitations regarding methodology and scope of data. For further research, it is needed to initiate analysing data collected from various higher educational institutions on national (Republic of Serbia), regional (former Yugoslavia or Western Balkans), and international level (EU and non-EU countries, the United States and other developed counties, etc.), which would give an insight to the point of view of different national cultures in the countries with diverse economic and social development.

\section{CONCLUSION}

In the second decade of the $21^{\text {st }}$ century, as the number of online courses is constantly growing, there are ongoing discussions on the value of online classes in all levels of formal and informal education, especially in higher education. The pandemic of Covid-19 disease caused by a Corona Virus (SARS-CoV-2) forced most of the higher education institutions in Europe to transfer, at least for a short period, almost the entire educational process to online platforms.

This paper examined the literature on the approaches to effective teacher-student communication, knowledge transfer, and development of students' critical thinking during online classes and courses.

The findings of the research show that there is a statistically significant difference in the satisfaction of the teachers and students with the online classes' effectiveness in regard to the teacher-student communication, knowledge transfer, and development of students' critical thinking. Furthermore, during short interviews with students and teachers, it can be concluded that the students are more satisfied with knowledge transfer, teacher-student communication, and the development of students' critical thinking skills during online classes than the professors. As the sample is small, further empirical research on the wider sample is needed in order to get more compelling conclusions.

This paper presented a model for the approach to further curricula development of online courses that would develop effective teacher - students' interaction, means of establishing knowledge transfer and modes of discussions that would improve the critical thinking of the students.

\section{REFERENCES}

Alawamleh, M., Al-Twait, L.M. and Al-Saht, G.R. (2020), "The effect of online learning on communication between instructors and students during Covid-19 pandemic", Asian Education and Development Studies, Vol. ahead-of-print No. ahead-of-print. https://doi.org/10.1108/AEDS-06-2020-0131

Alexander, M. M. et al. (2014) 'Snapshot of a Hybrid Learning Environment', Quarterly Review of Distance Education, 15(1), pp. 9-21. Available at: http://search.ebscohost.com/login. aspx ?direct=true $\& d b=a 9 h \& A N=97849238 \&$ site=eho st-live (Accessed: 13 November 2020).

Aristovnik A, Keržič D, Ravšelj D, Tomaževič N, Umek L. (2020) Impacts of the COVID-19 Pandemic on Life of Higher Education Students: A Global Perspective. Sustainability; 12(20):8438. https://doi.org/10.3390/su12208438 
Baker, R. et al. (2019) 'Does Inducing Students to Schedule Lecture Watching in Online Classes Improve Their Academic Performance? An Experimental Analysis of a Time Management Intervention', Research in Higher Education, 60(4), pp. 521-552. doi: 10.1007/s11162-018-9521-3.

Bettinger, Eric P., Lindsay Fox, Susanna Loeb, and Eric S. Taylor. (2017) "Virtual Classrooms: How Online College Courses Affect Student Success." American Economic Review, 107 (9): 2855-75. DOI: 10.1257/aer.20151193

Chen, Y.J., Chen, P. C. (2007) 'Effects of Online Interaction on Adult Students' Satisfaction'. The Journal of Human Resource and Adult Learning Vol. 3, Num. 2, December 2007, pp. 77-89.

Chirikov, I., Semenova, T., Maloshonok, N., Bettinger, E., \& Kizilcec, R.F. (2020). Online education platforms scale college STEM instruction with equivalent learning outcomes at lower cost. Science Advances, 6(15).

Desai, D. et al. (2020) 'Assessment of online teaching as an adjunct to medical education in the backdrop of COVID-19 lockdown in a developing country - An online survey', Indian Journal of Ophthalmology, 68(11), pp. 2399-2403. doi: 10.4103/ijo.IJO_2049_20.

Drugas, M. I. (2020) 'Teaching Psychology during the Covid-19 Pandemic. Challenges for Online Courses', Psychological Thought, 13(2), pp. 273-285. doi: 10.37708/psyct.v13i2.541.

Engle, J. P. (2020) 'Assuring Quality in Pharmacy Education During a Time of Crisis', American Journal of Pharmaceutical Education, 84(6), pp. 646-650. doi: 10.5688/ajpe8135.

Estacio, R.R. and Raga Jr, R.C. (2017) "Analyzing students online learning behavior in blended courses using Moodle", Asian Association of Open Universities Journal, Vol. 12 No. 1, pp. 52-68. https://doi.org/10.1108/AAOUJ-01-2017-0016

Heard, J., Scoular, C., Duckworth, D., Ramalingam, D., \& Teo, I. (2020). Critical thinking: Definition and structure. Australian Council for Educational Research. https://research.acer.edu.au/ar_misc/38

Hermond, D. and Tanner, T. (2020) 'Mastering Critical Thinking Competencies in Online Graduate Classes', Administrative Issues Journal: Education, Practice \& Research, 10(1), pp. 47-58. doi: 10.5929/2020.10.1.4.

Hollis, L. P. (2018) 'Ghost Students and the New Wave of Online Cheating for Community College Students', New Directions for Community Colleges, 2018(183), pp. 25-34. doi: 10.1002/cc.20314.

Narodna skupština Republike Srbije (2020) Odluka o ukidanju vanrednog stanja. "Službeni glasnik RS", broj 65 od 6. maja 2020. Available at: https://www.pravno-informacionisistem.rs/S1GlasnikPortal/eli/rep/sgrs/skupstina/odluka/2020/65/1/reg. (Accessed: 19 May 2020).

Parks-Stamm, E. J., Zafonte, M. and Palenque, S. M. (2017) 'The effects of instructor participation and class size on student participation in an online class discussion forum', British Journal of Educational Technology, 48(6), pp. 1250-1259. doi: 10.1111/bjet.12512.

Pažun, B., \& Langović, Z. (2020). Cloud computing concept in education systems. Serbian Journal of Engineering Management, 5(2), 25-32.

Republika Srbija. (2017) Zakon o visokom obrazovanju. [Higher Education Law]. Službeni glasnik Republike Srbije, br 88/2017, 27/2017. Beograd: Službeni glasnik Republike Srbije.

Roy, H. et al. (2020) 'A Study on Students' Perceptions for Online Zoom-app based Flipped Class Sessions on Anatomy Organised during the Lockdown Period of COVID-19 
Epoch', Journal of Clinical \& Diagnostic Research, 14(6), pp. 1-4. doi: 10.7860/JCDR/2020/44869.13797.

Službeni glasnik. (2020), Odluka o proglašenju vanrednog stanja. "Službeni glasnik RS”, broj 29 od 15. Marta 2020. Available at https://www.pravno-informacionisistem.rs/SlGlasnikPortal/eli/rep/sgrs/predsednik/odluka/2020/29/1/reg (Accessed: 22 April, 2020).

Trout, B. S. (2020) 'The Coronavirus-Induced Transition to Online Learning: Perceptions and Intentions of First-Time Online Students', Quarterly Review of Distance Education, 21(1), pp. $1-11$. Available at: http://search.ebscohost.com/login.aspx?direct=true \&db=a9h\&AN=146721347\&site=eh ost-live (Accessed: 13 November 2020).

Yang, Yi; Cornelius, Linda F. (2004) Students' Perceptions towards the Quality of Online Education: A Qualitative Approach. Association for Educational Communications and Technology, 27th, Chicago, Il. October 19-23 2004. https://files.eric.ed.gov/fulltext/ED485012.pdf (Accessed: 13 November 2020).

Zhu, X., \& Liu, J. (2020). Education in and After Covid-19: Immediate Responses and LongTerm Visions. Postdigital Science and Education, 1-5. Advance online publication. https://doi.org/10.1007/s42438-020-00126-3 